\title{
"Corresponding with the Professor": A Didactic Tool for Fostering Students' Ability to Identify Scholastic Difficulties and Ways of Coping with Them
}

\author{
Anna Prusak ${ }^{1,2}$, Atara Shriki ${ }^{2,3}$ \\ ${ }^{1}$ Sha'anan Academic Religious Teacher's College, Haifa, Israel \\ ${ }^{2}$ Oranim Academic College of Education, Tivon, Israel \\ ${ }^{3}$ Technion-Israel Institute of Technology, Haifa, Israel \\ Email:anaprusak@gmail.com, atarashriki@gmail.com
}

How to cite this paper: Prusak, A., \& Shriki, A. (2017). "Corresponding with the Professor": A Didactic Tool for Fostering Students' Ability to Identify Scholastic Difficulties and Ways of Coping with Them. Creative Education, 8, 1702-1719. https://doi.org/10.4236/ce.2017.810116

Received: July 13, 2017

Accepted: August 18, 2017

Published: August 21, 2017

Copyright (ङ 2017 by authors and Scientific Research Publishing Inc. This work is licensed under the Creative Commons Attribution International License (CC BY 4.0).

http://creativecommons.org/licenses/by/4.0/

\begin{abstract}
During their school years, students encounter difficulties of various types from both content-related and emotional aspects. Often, when asked directly about their learning difficulties, students struggle to express these difficulties explicitly and clearly; as a result, teachers find it a challenge to provide them with a suitable and satisfactory response. In order to help students express their scholastic difficulties, particularly cognitive and emotional ones, and foster their ability to chart out courses of action for coping with these difficulties, we have developed a tool we call "Corresponding with the Professor". Specifically, this involves writing a letter to an imaginary Professor which contains a description of a difficulty (or difficulties) followed by writing a detailed letter of response from the Professor (to oneself actually) that offers suggestions and recommendations aimed at possible ways of coping with the difficulty (or difficulties). In developing this tool, we have relied on research literature related to writing a "letter to myself". In this paper, we shall present the tool and its theoretical basis.
\end{abstract}

\section{Keywords}

Emotional Struggle, Scholastic Difficulties, Teacher Support, Written Expression, Writing to Myself, Written Reflection

\section{Introduction}

During the course of their school studies, students encounter scholastic difficulties of different types that originate from various sources (e.g. Durlak, Weiss- 
berg, Dymnicki et al., 2011; Roodra, Koomen, Split et al. 2011; Rozek \& Stobäus, 2016). Often, when asked directly about their learning difficulties, students struggle to put them clearly into words and, as a result, teachers struggle to adequately address those difficulties (Kearney, 2013; Rubie-Davies, 2010). In recent years, awareness has grown of the importance of listening to students' voices so as to deepen teachers' insights concerning their students' learning processes and to become more familiar with their worlds. Accordingly, teachers are involving the students in processes that concern their lives (e.g. DeFur \& Korinek, 2010). Listening to students' voices can be achieved, among other ways, by allowing students to express themselves in writing. Writing has a broad variety of functions. The psychologist Vygotsky (1986) considered written expression to be a sort of "internal speech", a person talking with himself', which constitutes a more conscious volitional expression than oral speech. One of the practices of writing is the therapeutic practice, which allows a person to be "his own healer" as he deals deeply with issues that trouble him. One possible application of this practice is "writing a letter to myself", an accepted approach in psychology and psychotherapy that has been found to be an efficient tool for solving personal problems on a number of different levels. This sort of writing has been shown to support the development of an individual's ability to deal intensely with his feelings, internal motives and barriers, and assists him in solving his problems on his own. This approach can also be applied by writing a letter to an imaginary addressee, followed by writing a "response letter" (to oneself) on behalf of the same addressee, including recommendations on ways of coping with the problem (Gray, 1992).

In order to help students express their difficulties and find ways of coping with them, we have developed a tool we call "Corresponding with the Professor"writing a letter to an imaginary Professor that contains a description of a difficulty followed by writing a detailed letter of response from the Professor (to oneself actually) that offers suggestions for ways of managing the difficulty. The initial version of this tool was developed by Prusak (2003). The version presented in this paper is the updated version after having undergone experimentation over the past 10 years. Formative studies that accompanied the development of the tool involved the participation of diverse academic groups (students, teachers and teacher-instructors) from different cultures, with a focus on difficulties associated with the learning and teaching of mathematics. With regard to students, their perceptions were examined in light of the tool's contribution to their ability to successfully deal with difficulties in preparing mathematics homework, preparing for mathematics exams and being tested, as well as other difficulties in assorted mathematical topics. In this paper, we will present the tool and its theoretical background without addressing the findings of studies that accompanied the process of developing the tool. We should mention here that these findings positively point to the tool's major contribution in developing students' ability to identify their scholastic difficulties and the source of the difficulties, and to develop their own ability to draw up a personal action plan for dealing with those difficulties.

${ }^{1}$ Throughout this paper, we employ the male gender solely for purposes of convenience. Naturally, we refer to males and females alike. 


\section{Theoretical Background}

\subsection{The Importance of Listening to Students' Voices}

During the course of their school studies, students encounter difficulties of different types-cognitive, emotional, personal, social, and functional-stemming from a range of causes. Teachers are cognizant of the fact that students experience difficulties, however in the majority of cases they are unaware of the nature and essence of the difficulties, as well as their sources. This lack of teacher awareness of students' difficulties stems from two principal causes: 1) teachers' inconvenience in asking students questions concerning their own difficulties; and 2) students' trouble in clearly expressing or formulating their difficulties, including cases where they are asked about them directly (Prusak, 2016; 2017). This has implications on teachers' lack of familiarity with the worlds of their students, their inability to provide their students with an adequate response, and students' increasing feelings of frustration, occasionally leading to a sense of what Seligman (1972; 2002) described as "learned helplessness".

All this suggests the importance of identifying a way of allowing students to describe their difficulties, which is in line with the value attributed in the past decade to listening to students' voices and encouraging them to take an active part in their own learning process (e.g. DeFur \& Korinek, 2010; Logan \& Skamp, 2008). This is founded on the belief that in doing so, students' learning experience will become more meaningful and that their commitment to learning and to school will grow stronger (Hargreaves, 2004). Moreover, listening to students' voices allows teachers to ascertain rich and in-depth information concerning their students' learning processes and thus adapt the learning environment and pedagogy to their needs (Ferguson, Hanreddy, \& Draxton, 2011). Obviously, in order for students to be able to express their opinions openly and without fear, it is essential to build a genuine and reciprocal trusting relationship between students and teachers while encouraging students to express themselves (Levin, 2000; Mitra, 2004).

The above material leads us to the necessity of finding a way to motivate students to express themselves. Generally, people express themselves in a broad variety of ways, including orally, in writing, through body movements, playing music, drawing and more. In this paper we focus on written expression, specifically letters a person writes to himself.

\subsection{Written Expression-Goals, Means and Methods}

In his book A Brief History of Humankind, Harari (2015) describes the timeline of history. According to this timeline, approximately 70,000 years ago mankind underwent a linguistic revolution and with it the development of cognitive abilities that led to a forward leap in human development. Writing began to develop more than 5000 years ago. Harari argues that the invention of writing is the result of the expansion of empires and the need to document and store information so as to maintain an organized and practical way of life. In contrast with animals, where the natural order is stored in their genes and passed down from 
generation to generation, in humans it is not part of their DNA, and therefore must be documented. Harari distinguishes between "partial writing", a system of signs that represent specific types of information (for example quantities and objects), and "complete writing", a system of signs that fully represents spoken human language and expresses the full gamut of human utterances. Over the years writing gradually developed from partial to complete writing, although not all cultures achieved total development in this regard.

Nowadays, scholars (e.g. Lobok, 1996) view written expression as the apex of the language pyramid and the most advanced achievement of human culture. In fact, from the moment people began expressing themselves in writing, it was possible to document events and interactions hitherto known only in real-time, i.e. in the here and now. This advance allows us to consider those same events for future generations. Aside from the historical documentation of discoveries, written expression enables interaction and the expression of thought and imagination via the exchange of letters or through the writing of poems, plays, stories and so forth. Furthermore, it has been found that often the very act of writing actually refines one's thinking or even makes thinking possible in the first place.

Written expression possesses unique characteristics that distinguish it from oral expression. One's choice of expression mode is personal and dependent on circumstances. The advantages and disadvantages of these two manners of expression have been investigated over the years by psychologists, educators, philologists, and others. In his book Thought and Language, the psychologist Lev Vygotsky (1986) deals with the connection between the psychological aspects of written and oral expression, where his starting point is the significant differences between the two types of expression. Vygotsky argued that written expression is not merely the translation of speech into written signs and that learning such expression does not end with learning the techniques of writing. If that were the case, we would expect that once the mechanism of writing was acquired, written expression would be no less developed or rich than speech, and would actually be similar to it, as a translation is to the source. Such a phenomenon, however, does not exist in the development of written expression abilities. Vygotsky considered written expression to be a sort of "written speech" or "inner speech" of a person with himself. He claimed that such expression is more complex and conscious than oral speech, since when a person talks he is not always aware of each word he utters, whereas when he writes, he needs to pay attention to the words he chooses and the way in which he builds sentences and connects them to each other.

In the research literature (e.g. Hunt \& Sampson, 1998), it is common to address three principal practices of writing: literary practices, process practices, and therapeutic practices; each with its own goal or purpose. Literary practices are aimed at generating some product for future publication. Such a product may contain expressions of position, perceptions, personal experience, fantasy and so forth. Writing of this sort typically contributes to strengthened self-esteem and self-confidence for the writer. Process practices are aimed at moti- 
vating some sort of process and they provide the individual with a tool of selfinquiry that can be applied at different stages of life. Therapeutic practices are aimed at both process and consequence. Therapeutic practice, particularly writing a letter to oneself, is at the center of the Corresponding with the Professor tool described in this paper, and we shall elaborate on it below.

Therapeutic practice enables a person to "be his own doctor" as he deals in-depth with issues that concern him. This practice may be applied in a variety of ways, the most common of which are writing a journal, expressive writing, and writing a letter to oneself:

- Therapy through journal writing may be applied by writing a structured or unstructured journal. An unstructured journal includes documentation of different occurrences, whether external or inner feelings, reflections on those occurrences, speculation, impressions and more. Typically, at some stage, the journal itself is abandoned and what remains is the experience of the person who wrote it. In the mid-1960s, Dr. Ira Progoff (1992), an American psychotherapist and social worker, suggested an economical and efficient psychological method that he called the "Intensive Journal Method". This method is meant to enable any individual to help himself by interacting with the internal processes he is undergoing, independently of the presence of a psychotherapist. This tool is accepted nowadays as a professional tool of self-inquiry.

- Expressive writing is a simple clinical technique that encourages people to write freely about their thoughts and feelings concerning stress factors (Pennebaker \& Beall, 1986). The American psychologist Dr. James Pennebaker (2004) reports that he developed this method after discovering that when people lack the option, or ability, to describe what is happening to them and share their feelings and thoughts with others, they develop chronic stress. Pennebaker's approach teaches how to build an organized and detailed story in which experiences and causal relations are described, with a focus on emotional and experiential aspects. He found that writing, for even $15-20 \mathrm{mi}-$ nutes, can provide physical and psychological relief (Gortner, Rude, \& Pennebaker, 2006).

- Writing a letter to oneself currently constitutes an accepted method in the field of personal coaching, psychology, psychotherapy and auto-therapy. It has been found to be an efficient solution to problems on the personal, family, social and professional levels. Traditionally, a letter is a written message from one person to another; however, a person can also write a letter to himself. The goal of writing a letter to oneself is to enable a person to develop his ability to deal in-depth with his feelings and motivations, and to assist him in solving problems on his own (Gray, 1992). When a person writes a letter to himself, he is observing himself and his problems from the side, addressing himself as if he were another person in need of help and as if he, the writer, very much wants to help him. In this way, it is easier for him to deal with his problems without self-criticism, while paying attention to details he had not noticed before, since he was controlled by his emotions at the time. That is to 
say, when a person undergoes any sort of experience, his feelings and thoughts are often not at the conscious level, but when a person writes certain things to himself, they become more concrete for him. Essentially, writing to oneself forces the writer to think about the internal logic of the text and to tell a sequential story. Thus, the writer creates order, clarity and logic in his mental world, develops insights, and builds new knowledge; in many cases a solution surfaces unexpectedly as a result of the writing (Modlinger, 2015). Writing also allows a person to, in a sense, evaluate himself, since at any time he may go back and read the letters he wrote to himself, comparing different perspectives at different times and assessing progress, regression and fixation (Bolton, 1999). Writing a letter to oneself provides a person with a secure environment in which he can express his feelings and cleanse himself of negative feelings. In a letter written to oneself, a person can tell himself things openly and courageously, including things that are not easily confronted. When a person devotes time to listening to his feelings he is actually sending himself a message that he is important and worthy of being listened to (Gray, 1992). Letters can be written to oneself in the past or in the future. A letter to oneself in the past requires the writer to observe himself from the side, analyze his life objectively, and arrive at conclusions including admitting mistakes and rethinking his system of values. The goal in such a case is to assist the individual in understanding and accepting himself. A letter to one's future self allows the writer to describe his present situation, arrive at conclusions with regard to his life's path up to the present time, emphasize what he has learned about life and about himself, make generalizations regarding his viewpoints and values and, based on all this, formulate what he expects from his future (Zander \& Zander, 2002). This approach can also be applied by a person writing a letter to an "imaginary" addressee in which he describes the problem he is facing. After this, the person writes a "letter of response" to himself on behalf of the same addressee that includes recommendations for ways of dealing with the problem. Dr. John Gray (1992) was among the first to recommend writing a letter to oneself with a corresponding letter of response as a method of healing and treatment, particularly during crises between spouses. In his book Men are from Mars, Women are from Venus, Gray points out that when a person is under the control of negative emotions towards his/her spouse (anger, confusion, sadness, disappointment, frustration, and so forth) it is preferable not to express those feelings orally, but rather to write the spouse a letter. This "love letter" technique that Gray suggests is composed of three stages: 1) writing the "love letter", in which the writer expresses his negative feelings; 2) writing the letter of response, where the writer describes what he would like his spouse to say in response to the "love letter"; and 3) sharing the content of both letters with the spouse. According to Gray, writing the love letter allows the writer to listen to his own feelings without fear of hurting his spouse. Consequently, the writer develops an awareness of the intensity of his feelings and can release 
some of the intensity; he becomes less judgmental and accusatory, and is more available and open to positive feelings. In other words, the mere expression of feelings in writing serves as a beneficial instrument for improving the situation. The stage of composing the letter of response is an important steppingstone in the process of self-healing and can actually have an even greater effect than writing the love letter itself. In composing the letter of response, the writer needs to write down the response he expects to receive from the spouse even as he tries to imagine a loving response to the hurt feelings described in the love letter. It is important that while writing the response, the writer pretend that his/her spouse is actually writing it. In many cases people are not open to receiving assistance or support, yet writing the letter of response constitutes de facto recognition of one's readiness to receive assistance. It is not necessary to share the letters with the spouse, although by reading the letters, the spouse can learn about the needs of the writer. Gray recommends applying this technique for the purpose of writing letters to different addressees - a person close to oneself, a friend, a child, a family member, a colleague, a client and others-with a corresponding letter of response written on behalf of the addressee. Generally speaking, it can be said that writing the first letter enables the writer to describe and examine the problem. Writing the letter of response allows the writer to think of solutions and ways of dealing with the problem while recruiting his own personal knowledge and skills and discovering positive, internal hidden forces (Kutuzova, 2009; Zander \& Zander, 2002).

\subsection{Writing in School Setting}

In recent years, much has been said about students having lost their writing skills and ability to express themselves in writing due to the availability of technology and widespread habits of expressing feelings through symbols or syllables in place of words. Space does not allow us to cover the large corpus of writing in this context (for a review, see for example Carter \& Harper, 2013) or, as well, the literature that expresses the importance of developing writing skills in the school setting. Traditionally, in acquiring writing skills, students practice for a long period of time by copying texts written by others. Later, when the students are given assignments involving writing, many of them search for answers on the internet, copying full sections without any inspection. It seems that this reality has resulted in students losing interest in written self-expression and thereby losing the associated skills. One of the implications of this situation is a decrease in the scope of reading among teenagers, accompanied by the development of employing poor language habits (Rosen, Chang, Erwin, Carrier, \& Cheever, 2010). Still, one must remember that children of the iGeneration are opinionated and have something to say about virtually everything (Rosen, 2011). Therefore, it would appear that developing their ability to express themselves in writing could help them "encounter themselves" through the writing of their personal stories, since the unique characteristics of written expression support the per- 
sonal development of children (Vygotsky, 1986; 1997).

Vygotsky (1986) maintained that in contrast to oral expression, children do not spontaneously develop the ability to express themselves in writing. For this purpose, focused pedagogical guidance is necessary, and since writing is an expression of personal creation, children need to be given suitable conditions for developing this skill, together with explicit and continuous guidance. In his time, Vygotsky felt that schools were not dedicating sufficient attention to developing students' ability to express themselves in writing. Today, too, researchers (e.g. Vinokourova, 2008) point out that teachers are not putting enough emphasis on nurturing this skill. Modlinger (2015) suggests replacing the requirement of "let them read!", popular in the 1970s, with the contemporary "let them write"; especially in view of the fact that these are, in essence, two different linguistic skills.

Furthermore, after surveying the literature, we found that while much has been written about students' reading difficulties and suitable ways of overcoming them, when it comes to writing difficulties, the literature mainly discusses difficulties stemming from different types of learning disabilities. There is scarce literature dealing with difficulties stemming from the emotional aspects of writing and the barriers that prevent students from expressing themselves. This situation is somewhat puzzling, since for many years it has been customary to view the principle of humanization as the guiding principle in the work of educators (e.g. Sakhieva, Semenova, Muskhanova et al., 2015). The significance of this principle is to recognize that we must devote special attention to children's internal worlds and the difficulties and problems they encounter in their school studies, and endeavor to provide them with efficient tools for dealing with their difficulties.

A few studies deal with the contribution of expressive writing or writing a letter to oneself in the school setting. Park, Ramirez and Beilock (2014), for example, examined the influence of expressive writing prior to taking a mathematics exam. The researchers found that writing contributed to both a reduction in mathematics and test performance anxiety, as well as improved grades. They believe that the act of writing has an effect on the writer's ability to distance himself from the immediate source of stress, and that expressive writing brings about a decrease in the mental resources devoted to concerns arising from the need to take an exam-thus making space available in the working memory to succeed in the assignment itself.

In light of the above, we asked ourselves how to integrate the "writing to oneself" approach in the school setting in a way that would address not only the need to develop expressive writing skills, but also provide students with the opportunity to express their difficulties and inform their teachers of the source of those difficulties.

The method we have chosen is the one suggested by Gray (1992), whereby a person writes a letter to an imaginary addressee, with a letter of response written by the same addressee. We have called the tool that we have developed "Corresponding with the Professor"-that is, writing a letter to an imaginary Professor 
in which the writer describes difficulties, followed by the writing of a detailed letter of response from the Professor that includes suggestions for a way of dealing with those difficulties.

Below we describe the tool we have developed and the theoretical basis of each of its components.

\section{The "Corresponding with the Professor" Didactic Tool}

The "Corresponding with the Professor" tool was designed to be implemented in a series of five consecutive stages:

- Stage 1-Students write a letter to the Professor in which they describe one or more primary difficulties in the context of a discussed issue (for example, preparing homework, preparing for an exam, being tested, difficulty in a specific topic, etc.);

- Stage 2-Students are asked to respond to a questionnaire and reflectively analyze the contribution that writing the letter to the Professor makes to their ability to identify their main difficulties and deal with these difficulties;

- Stage 3-The letters and questionnaire responses are collected and read by the teacher in order to learn about students' difficulties. The letters are later returned to the writers, while the feedback from the questionnaire remains with the teacher;

- Stage 4-Students read the letters they had written to the Professor and compose a response on behalf of the Professor in which he advises them on how to deal with the difficulties described in the letter;

- Stage 5-Students are asked to respond to a questionnaire and reflectively analyze the contribution that writing the letter of response on behalf of the Professor makes to their ability to identify difficulties and find ways of dealing with the described difficulties. In this context, students are also asked to compare the contributions of both letters they have written.

\subsection{Description of the "Corresponding with the Professor" Tool}

In what follows, we shall present the instructions given to students in stages 1, 2, 4 and 5 . The instructions refer to the case where the difficulty being discussed is related to the preparation of homework-in this specific case, mathematics homework.

\section{Stage 1-Instructions for writing a letter to the Professor}

Students are given a sheet with the following text:

Dear student,

In this assignment, you are asked to write a letter to an imaginary Professor according to the instructions below:

1) Please draw a picture of a bespectacled university math Professor with a pair of kindhearted and wise eyes; a person whom you trust to be capable of helping you deal with your difficulties in preparing math homework.

2) a) In the form of a letter, describe to the Professor your main difficulties related to preparing math homework. Write the letter in your own handwriting. 
You may begin the letter as follows:

"Dear Professor, I'm in need of your assistance. My greatest difficulties in preparing math homework are..."

b) Please try to explain to the Professor the source or reason for the difficulties you have described.

Stage 2-Reflecting on writing the letter to the Professor (feedback following carrying out the assignment)

After writing the letter to the Professor, students are asked to reflectively analyze the contribution of writing the letter to identifying their difficulties and to dealing with the difficulties they have described. They should also describe the feelings they had while writing the letter and what they subsequently learned about themselves. In order to help students reflect on the above, they are asked to fill in a questionnaire composed of four statements to which they have to indicate their degree of agreement (on a five-level Likert scale) followed by two open-ended questions. The following questionnaire is given to students:

\section{Dear student,}

You have just now written a letter to the Professor in which you described your difficulties in preparing math homework. The goal of this current assignment is to help you arrive at insights concerning the contribution of writing the letter to the Professor to your ability to identify the difficulties you pointed out and find suitable ways of dealing with the difficulties on your own.

For this purpose, please grade your level of agreement with the statements that appear below and give reasons for your grade. This will be followed by two questions for you to answer.

1) Presented below are several statements.

Please indicate your level of agreement with those statements.

$(1=$ Strongly disagree; 2 = Disagree; $3=$ Somewhat agree; $4=$ Agree; $5=$ Strongly agree)

\begin{tabular}{|c|c|c|c|c|c|c|}
\hline & & \multicolumn{4}{|c|}{ Level of Agreement } & Reason for this grade \\
\hline \multicolumn{6}{|c|}{ Writing the letter to the Professor } & \\
\hline 1 & $\begin{array}{l}\text { Helped me identify my main difficulties } \\
\text { in preparing math homework }\end{array}$ & 1 & 2 & 3 & 4 & \\
\hline 2 & $\begin{array}{l}\text { Helped me understand how to deal with my } \\
\text { main difficulties in preparing math homework }\end{array}$ & 1 & 2 & 3 & 4 & \\
\hline 3 & $\begin{array}{l}\text { Had a positive effect on my attitude } \\
\text { towards math homework }\end{array}$ & 1 & 2 & 3 & 4 & \\
\hline 4 & $\begin{array}{l}\text { Will, in my opinion, contribute to my success } \\
\text { in preparing math homework in the future }\end{array}$ & 1 & 2 & 3 & 4 & \\
\hline
\end{tabular}

2) What did you feel when you described your main difficulties in preparing math homework to the Professor?

3) What did you learn about yourself as a result of writing the letter to the Professor and by answering Question 2? 
Stage 3-Instructions for writing a letter of response on behalf of the Professor

After the students have written the letter to the Professor, the teacher collects the letters and reads them in order to learn about students' difficulties. Then, the teacher returns the letters to the students and gives them a sheet on which it is written:

\section{Dear student,}

Please reread the letter you wrote to the Professor and reflect on it.

Afterwards, please handwrite a detailed letter of response to yourself on behalf of the Professor in which she or he gives you recommendations and instructions on practical ways of dealing with the difficulties you had described.

Stage 4-Reflective analysis of writing the letter of response from the Professor (feedback following carrying out of the assignment)

Similarly to Stage 2, after writing the letter students are asked to analyze reflectively the contribution of writing the response letter to their ability to identify their difficulties and to their ability to deal with the difficulties they have described. Additionally, students should reflectively analyze the feelings they had when writing the letter and the things they learned about themselves after writing it. Then, the students are asked to compare between the contributions of writing each of the letters.

Administer the following questionnaire to the students:

\section{Dear student,}

You have just written a letter of response on behalf of the Professor in which you proposed suitable ways of dealing with the difficulties you described in the letter to the Professor. The goal of this current assignment is to help you arrive at insights concerning the contribution of writing the response letter to your ability to identify the difficulties you pointed out and find suitable ways of dealing with the difficulties on your own.

For this purpose, please grade your level of agreement with the statements that appear below and give reasons for your grade. This will be followed by three questions for you to answer.

1) Presented below are several statements.

Please indicate your level of agreement with those statements.

$(1=$ Strongly disagree; $2=$ Disagree; $3=$ Somewhat agree; $4=$ Agree; $5=$ Strongly agree)

\begin{tabular}{|c|c|c|c|c|c|c|}
\hline & & \multicolumn{4}{|c|}{ Level of Agreement } & Reason for this grade \\
\hline \multicolumn{6}{|c|}{ Writing a letter of response on behalf of the Professor... } & \\
\hline 1 & $\begin{array}{l}\text { Helped me identify my main difficulties } \\
\text { in preparing math homework }\end{array}$ & 1 & 2 & 3 & 4 & \\
\hline 2 & $\begin{array}{l}\text { Helped me understand how to deal with my } \\
\text { main difficulties in preparing math homework }\end{array}$ & 1 & 2 & 3 & 4 & \\
\hline 3 & $\begin{array}{l}\text { Had a positive effect on my attitude } \\
\text { towards math homework }\end{array}$ & 1 & 2 & 3 & 4 & \\
\hline 4 & $\begin{array}{l}\text { Will, in my opinion, contribute to my success } \\
\text { in preparing math homework in the future }\end{array}$ & 1 & 2 & 3 & 4 & \\
\hline
\end{tabular}


2) What did you feel when you wrote the letter of response to yourself on behalf of the Professor?

3) What did you learn about yourself as a result of writing the letter of response and answering Question 2 above?

4) As far as you are concerned, what are the main differences between writing the letter to the Professor and writing a letter on behalf of the Professor?

\section{Comments}

1) Originally, the first letter (to the Professor) was meant to enable students to express their difficulties. Unexpectedly, we found that aside from merely describing their difficulties, some students suggested solutions to their difficulties despite not being asked to do so. Therefore, a second statement was added to the reflective questionnaire- "Helped me understand how to deal with my main difficulties [in preparing math homework]". Similarly, in analyzing the letters of response written by the students to themselves, on behalf of the Professor, we found that students wrote additional difficulties, beyond the difficulties identified when writing the first letter. Therefore, both reflective questionnaires include the same statements, as attention is drawn to the difficulties and also the ways of dealing with them. Moreover, the fact that both reflective questionnaires are identical allowed us to discover the added value of writing the second letter relative to writing the first one.

2) In order for teachers to derive the maximum benefit from the letters written by students, we recommend that they give their opinions in response to questions such as:

a) What have I learned from students' letters about their difficulties [in preparing homework] in terms of content, emotional and personal aspects? Did the letters help me ascertain their main difficulties [in preparing homework] of which I was not aware previously? If so, what exactly were those difficulties that were revealed to me?

b) What did I learn from my students' responses to the reflective questionnaires concerning the contribution of the "Corresponding with the Professor" tool to their ability and readiness to express difficulties that they do not overtly express in another way?

c) What did I learn from students' informal responses concerning their experience in writing the letters? What atmosphere did this generate in the classroom?

\subsection{Theoretical Basis of the Components of the "Corresponding with the Professor" Tool}

The components of the "Corresponding with the Professor" tool were developed based on research literature in the field of psychology and psychotherapy:

- The Professor as the addressee-Literature dealing with "writing a letter to myself" (e.g. Gray, 1992) indicates the importance of conveying a letter to an imaginary addressee in cases that involve the personal difficulties of the writer. Ostensibly, one could choose an imaginary mathematics teacher as the 
imaginary addressee, but we felt it possible that students who had been disappointed in the past with the support or help given to them by their teacher would project this memory and fail to write about their difficulties. A Professor, on the other hand, is perceived as an authoritative figure with expertise in his or her field and who does not have a direct influence on what is happening in school. Therefore, our assumption was that students would trust the professionalism of a Professor as the figure they were addressing and not fear exposing themselves to him or her. Moreover, while writing the letter of response, the students need to put themselves in the shoes of a figure whom they perceive as capable of dispensing efficient advice for dealing with their difficulties (Kudrina, 2009).

- Drawing the figure of the Professor-The request to draw the figure of the Professor with whom they are exchanging letters is meant to enable students to get closer to the figure they are writing to. Doing so strengthens their trust in the Professor and generates a sort of "intimacy" between them that is aimed at helping students write openly about their difficulties. The drawing of the figure of a "personal" Professor function as a "visual metaphor"-a recognized tool in the field of auto-psychotherapy (self-administered therapy aimed at independently solving problems by referring to accumulated experience in one's subconscious). Such a metaphor becomes a "visual anchor". The importance attributed to this technique stems from the fact that conflicts at the subconscious and inner emotional level are easier to express through visual images rather than verbally, since such images are devoid of internal censorship (Myagkova, 2002; Serig, 2006).

- Hand-writing the letter (as opposed to typing it on a computer)-Psychologists and experts who engage in writing practices point out that handwriting is more efficient than typing on a computer in terms of its effect on the writer's ability to enter an emotional state that allows him to express himself profoundly (Progoff, 1992; Kutuzova, 2012). Accordingly, students are asked to hand-write the letters.

- Writing an opening sentence-An opening sentence puts the writer on a specific writing path and directs him towards the intended purpose of the letter (Gray, 1992). Therefore, it is suggested to students that they open the letter to the Professor by indicating that they are in need of his or her assistance and follow with a description of their difficulties.

\section{Concluding Remarks}

From discussions we have held with teachers over the years, we have found that many admit that they often fail to solve their students' scholastic problems solely based on verbal conversations with them. Often, teachers find themselves obliged to have those same conversations over and over again, without reaching a satisfactory solution to the problem. Teachers believe that possible reasons for not being able to understand the source of students' problems might be for the fact that they do not feel sufficiently secure to reveal the causes for their difficul- 
ties or the difficulties they have in expressing themselves during verbal conversations. Many of the teachers who integrated the "Corresponding with the Professor" didactic tool believe that providing students with the opportunity to write down their difficulties, while simultaneously devising ways of dealing with those difficulties on their own, is far more valuable than a verbal conversation. This is particularly true given that, in such conversations, teachers typically do not ask the students what they suggest as a solution. Teachers are of the opinion that the key value of writing the letters lies in the transitioning of students from a situation in which they blame external factors for their difficulties or failures, to one in which they take personal responsibility for their learning. Additionally, and most importantly, students discover their ability to help themselves. Furthermore, even teachers who believe that they pay close and personal attention to their students admit to not being able to reach each of their students in depth. The letter-writing enabled them to become directly and more intimately familiar with the worlds of each one of their students.

As mentioned, the process of developing the "Corresponding with the Professor" didactic tool and examining its effect on teachers and students was accompanied by research over the past ten years (see for example Prusak, 2016). Based on our accumulated experience in using this tool, we wish to shed light on several issues:

- Many teachers are not accustomed to writing down their difficulties. We therefore recommend that teachers start by trying out the tool on themselves. As regards the issue of homework, for example, teachers can write the Professor about the difficulties they experience with their students in this regard and later write themselves a letter of response on behalf of the Professor, with operative recommendations for dealing with those difficulties. Naturally, teachers can try out the tool in any other context relevant to their professional lives (for example, general issues concerning teacher-student interactions, difficulties experienced within the school system, and so forth). It is also recommended that teachers respond to the two reflective questionnaires. From our experience, teachers who have personally experienced the tool were better able to appreciate its potential and succeeded in integrating it more easily into their classrooms, thus deriving more benefit from it.

- An essential condition for successful implementation of the tool in the classroom concerns teachers' belief in the ability of their students to express themselves authentically, profoundly and extensively. Often, teachers are doubtful about students' ability to express their difficulties and suggest solutions in writing; therefore, they avoid integrating the tool in their classroom. However, over the years, we have discovered that students write letters filled with emotion and profound insights, and even express gratitude for the opportunity given them to articulate their difficulties.

- Understandably, not all students are willing to cooperate and write the letters. For some of them, exposure is not a simple matter; others have doubts as to their teacher's sincere interest in their difficulties. Therefore, it is im- 
portant that teachers consider suitable ways of preparing their students for writing so as to ensure their cooperation while at the same time allaying their resistance. Teachers can, for example, confide to their students that they are worried by the fact that recently there has been a decline in homework preparation and that it is important to ascertain and understand why students are struggling. Moreover, teachers can tell the students that they believe in their ability to find a way to help themselves cope with their difficulties, and for this purpose they wish to embark on a journey with them during which the students will write about their difficulties in preparing homework assignments, sincerely and in depth, as well as about the source of those difficulties.

- It is recommended that students write the letters and respond to the reflective questionnaires during the school day, while in class, rather than at home. From our experience, the fact that all of the students write about their difficulties concurrently generates an "extenuating situation" that relieves pressure and allows them to express themselves openly. Later, writing the letters often provokes spontaneous discussion among students and improves their interaction. Students express interest in the various difficulties acknowledged by their classmates and derive encouragement from the fact that they are not the only ones encountering difficulties. Frequently, students offer assistance or solutions to their classmates, thus generating a sense of being able to help not only themselves but their friends as well. An open dialogue such as this encourages students who have avoided writing a letter to try it out in the next time.

- We find it important to point out that as students progress from assignment to assignment, their reflective ability develops further, and the advice they give themselves in the Professor's letter of response becomes more practical, efficient and detailed. Furthermore, with time, students tend to attribute an even greater contribution of the letter-writing tool and its potential to a positive impact on their subsequent studies.

In light of the above positive feedback, we recommend that teachers in all disciplines apply this tool in their classrooms so as to learn, up close, about their students' difficulties, hardships and expectations, on the one hand, and, on the other hand, to enable their students to develop and hone skills which help them, academically as well as personally, now and in the future.

Teachers interested in participating in an international study which will focus on the contribution of the "Corresponding with the Professor" didactic tool in connection with various different disciplines, issues, student populations and cultural backgrounds, are invited to write us.

\section{References}

Bolton, G. (1999). The Therapeutic Potential of Creative Writing: Writing Myself. London and Philadelphia: Jessica Kingsley Publishers.

Carter, M. J., \& Harper, H. (2013). Student Writing: Strategies to Reverse Ongoing Decline. Academic Questions, 26, 285-295. 
https://doi.org/10.1007/s12129-013-9377-0

DeFur, S. H., \& Korinek, L. (2010). Listening to Student Voices. The Clearing House: A Journal of Educational Strategies, Issues and Ideas, 83, 15-19. https://doi.org/10.1080/00098650903267677

Durlak, A. L., Weissberg, R. P., Dymnicki, A. B., \& Schellinger, K. B. (2011). The Impact of Enhancing Students' Social and Emotional Learning: A Meta-Analysis of SchoolBased Universal Interventions. Child Development, 82, 405-432. https://doi.org/10.1111/j.1467-8624.2010.01564.x

Ferguson, D. L., Hanreddy, A., \& Draxton, S. (2011). Giving Students Voice as a Strategy for Improving Teacher Practice. London Review of Education, 9, 55-70. https://doi.org/10.1080/14748460.2011.550435

Gortner, E. M., Rude, S. S., \& Pennebaker, J. W. (2006). Benefits of Expressive Writing in Lowering Rumination and Depressive Symptoms. Behavior Therapy, 37, 292-303.

Gray, J. (1992). Men Are from Mars, Women Are from Venus: A Definitive Guide to Relationships. HarperCollins Publishers.

Harari, Y. N. (2015). Sapiens: A Brief History of Humankind. HarperCollins Publishers.

Hargreaves, D. (2004). Personalising Learning-2, Student Voice and Assessment for Learning (pp. 1-16).

https://actionlearning-knox.wikispaces.com/file/view/Student+voice+and+assessment + for+learning+-+Cahpters+1+and+2.pdf

Hunt, C., \& Sampson, F. (1998). Introduction. In C. Hunt, \& F. Sampson (Eds.), The Self on the Page: Theory and Practice of Creative Writing in Personal Development (pp. 9-18). Jessica Kingsley Publishers. https://doi.org/10.5840/cssr199835

Kearney, E. M. (2013). On Becoming a Teacher. Sense Publishers. https://doi.org/10.1007/978-94-6209-392-8

Kudrina, A. V. (2009). Methods of Art-Therapy in Practice of Psychological Counseling. Dubna Psychological Journal, 3. (In Russian) http://www.psyanima.su/journal/2009/3/2009n3a5/2009n3a5.pdf

Kutuzova, D. (2009). Keeping a Diary of Structured Method I. Progoff. Moscow Psychotherapeutic Journal, 1, 126-140. (In Russian)

Kutuzova, D. (2012). Write or Print? (In Russian) http://www.pismennyepraktiki.ru/pisat-ili-pechatat/

Levin, B. (2000). Putting Students at the Centre in Education Reform. International Journal of Educational Change, 1, 155-172. https://doi.org/10.1023/A:1010024225888

Logan, M. R., \& Skamp, K. R. (2008). Engaging Students in Science across the Primary Secondary Interface: Listening to the Students' Voices. Research in Science Education, 38, 501-527. https://doi.org/10.1007/s11165-007-9063-8

Lobok, A. M. (1996). Dialogue with L. S. Vygotsky on the Written Speech. Voprosy Psychologiiy, 6, 41-52. (In Russian) http://www.voppsy.ru/issues/1996/966/966041.htm

Mitra, D. L. (2004). The Significance of Students: Can Increasing "Student Voice" in Schools Lead to Gains in Youth Development? Teachers College Record, 106, 651-688. https://doi.org/10.1111/j.1467-9620.2004.00354.x

Modlinger, I. (2015). About Writing. (In Hebrew) http://techedu.huji.ac.il/learning/dys/disgraphia1.html

Myagkova, I. (2002). Visual Metaphor in Psychotherapeutic Work. (In Russian) http://psytop.com/content/view/227/6/

Park, D., Ramirez, G., \& Beilock, S. L. (2014). The Role of Expressive Writing in Math 
Anxiety. Journal of Experimental Psychology, 20, 103-111. https://doi.org/10.1037/xap0000013

Pennebaker, J. W. (2004). Writing to Heal: A Guided Journal for Recovering from Trauma \& Emotional Upheaval. Raincoat Books.

Pennebaker, J. W., \& Beall, S. K. (1986). Confronting a Traumatic Event: Toward an Understanding of Inhibition and Disease. Journal of Abnormal Psychology, 95, 274-284. https://doi.org/10.1037/0021-843X.95.3.274

Progoff, I. (1992). At a Journal Workshop: Writing to Access the Power of Unconscious and Evoke Creative Ability. Penguin Putnam, Inc.

Prusak, A. (2003). The Nature and Role of Cultural Factors in the Learning of Mathematics. Unpublished Doctoral Dissertation. Israel: The University of Haifa. (In Hebrew)

Prusak, A. (2016). "Dear Professor, I Need Your Advice”: Correspondence with an Imaginary Professor as a Tool for Students to Uncover and Manage Their Learning Difficulties. In XVII L.S. Vygotsky International Readings "Cultural-Historical Psychology: From Scientific Revolution to Transformation of Social Practices” (pp. 239-246). Moscow.

Prusak, A. (2017). Writing "Letters to the Professor"-A Didactic Means for Assisting Students in Identifying Their Learning Difficulties in Mathematics and Appropriate Ways to Deal with the Difficulties. In The Fifth Jerusalem Conference on Research in Mathematics Education. Israel: Jerusalem College of Technology. (In Hebrew)

Roodra, D. L., Koomen, H. M, Y., Split, J. L., Frans, J., \& Oort, F. J. (2011). The Influence of Affective Teacher-Student Relationships on Students' School Engagement and Achievement: A Meta-Analytic Approach. Review of Educational Research, 81, 493529.

Rosen, L. D. (2011). Teaching the I Generation. Educational Leadership, 68, 10-15.

Rosen, L. D., Chang, J., Erwin, L., Carrier M. L., \& Cheever, N. A. (2010). The Relationship between "Textisms" and Formal and Informal Writing among Young Adults. Communication Research, 37, 420-440. https://doi.org/10.1177/0093650210362465

Rozek, M., \& Stobäus, C. D. (2016). Teachers Dealing with Learning Difficulties during the Process of Schooling. Creative Education, 7, 2696-2709.

https://doi.org/10.4236/ce.2016.717252

Rubie-Davies, C. M. (2010). Teacher Expectations and Perceptions of Student Attributes: Is There a Relationship? British Journal of Educational Psychology, 80, 121-135. https://doi.org/10.1348/000709909X466334

Sakhieva, R. G., Semenova, L. V., Muskhanova, I. V., Yakhyaeva, A. K., Iskhakova, R. R., Makarova, E. V., \& Shafigullina, L. S. (2015). Academic Mobility of High School Students: Concept, Principles, Structural Components and Stages of Implementation. Journal of Sustainable Development, 8, 256-262. https://doi.org/10.5539/jsd.v8n3p256

Seligman, M. E. P. (1972). Learned Helplessness. Annual Review of Medicine, 23, 407412. https://doi.org/10.1146/annurev.me.23.020172.002203

Seligman, M. E. P. (2002). Authentic Happiness: Using the New Positive Psychology to Realize Your Potential for Lasting Fulfilment. New York, NY: Free Press.

Serig, D. (2006). A Conceptual Structure of Visual Metaphor. Studies in Art EducationA Journal of Issues and Research, 47, 229-247.

Vinokourova, O. S. (2008). To the Problem of the Psychology of Written Speech. (In Russian) http://cyberleninka.ru/article/n/k-probleme-psihologii-pismennoy-rechi

Vygotsky, L. (1986). Thought and Language (Newly Revised and Edited by A. Kozulin). The Massachusetts Institute of Technology. 
Vygotsky, L. (1997). Educational Psychology. Boca Raton, FL: St. Lucie Press.

Zander, R. S., \& Zander, B. (2002). The Art of Possibility: Transforming Professional and Personal Life. Penguin Books.

\section{Scientific Research Publishing}

Submit or recommend next manuscript to SCIRP and we will provide best service for you:

Accepting pre-submission inquiries through Email, Facebook, LinkedIn, Twitter, etc. A wide selection of journals (inclusive of 9 subjects, more than 200 journals)

Providing 24-hour high-quality service

User-friendly online submission system

Fair and swift peer-review system

Efficient typesetting and proofreading procedure

Display of the result of downloads and visits, as well as the number of cited articles Maximum dissemination of your research work

Submit your manuscript at: http://papersubmission.scirp.org/

Or contact ce@scirp.org 